\title{
Abundance and Productivity of Marbled Murrelets (Brachyramphus marmoratus) Off Central California During the 2019 Breeding Season
}

Data Series 1123

U.S. Department of the Interior

U.S. Geological Survey 
Cover: Juvenile marbled murrelet (Brachyramphus marmoratus) off Santa Cruz, California. Photograph by David Presksta, Bureau of Ocean Energy Management, August 1, 2017. 


\section{Abundance and Productivity of Marbled Murrelets (Brachyramphus marmoratus) Off Central California During the 2019 Breeding Season}

By Jonathan J. Felis, Emily C. Kelsey, Josh Adams, Cheryl Horton, and Laney White

Data Series 1123 


\title{
U.S. Department of the Interior \\ DAVID BERNHARDT, Secretary
}

\author{
U.S. Geological Survey \\ James F. Reilly II, Director
}

U.S. Geological Survey, Reston, Virginia: 2020

For more information on the USGS - the Federal source for science about the Earth, its natural and living resources, natural hazards, and the environment—visit https://www.usgs.gov or call 1-888-ASK-USGS.

For an overview of USGS information products, including maps, imagery, and publications, visit https://store.usgs.gov/.

Any use of trade, firm, or product names is for descriptive purposes only and does not imply endorsement by the U.S. Government.

Although this information product, for the most part, is in the public domain, it also may contain copyrighted materials as noted in the text. Permission to reproduce copyrighted items must be secured from the copyright owner.

Suggested citation:

Felis, J.J., Kelsey, E.C., Adams, J., Horton, C., and White, L., 2020, Abundance and productivity of marbled murrelets (Brachyramphus marmoratus) off central California during the 2019 breeding season: U.S. Geological Survey Data Series 1123, 13 p., https://doi.org/10.3133/ds1123.

ISSN 2327-638X (online) 


\section{Acknowledgments}

We would like to thank our additional murrelet observer: Alex Rinkert, of California State Parks.

The University of California-Santa Cruz (UCSC) small boat program and Dave Benet (UCSC)

provided excellent vessel support and maintained the R/V Lucy M. We would also like to thank our additional vessel operators and truck drivers: Cordell Johnson (USGS) and Rob Wyland (USGS). Finally, we are grateful to Martin Raphael and Benjamin Becker for reviewing prior versions of this report. 


\section{Contents}

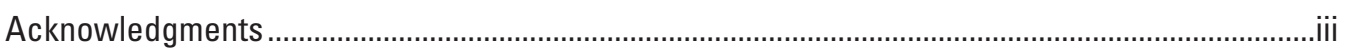

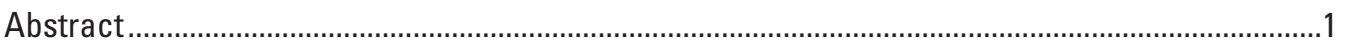

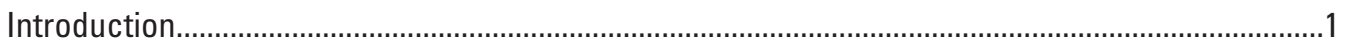

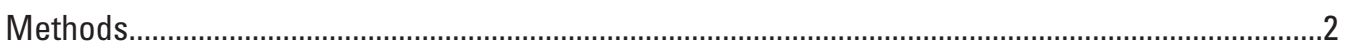

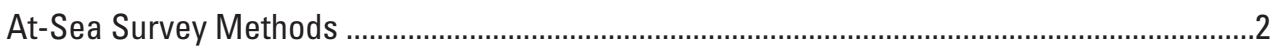

Abundance Estimation Methods ........................................................................................

Juvenile Ratio Estimation Methods ....................................................................................5

Marbled Murrelet Abundance and Productivity Results ...................................................................6

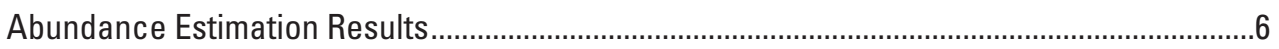

Productivity—Juvenile Ratio Results............................................................................

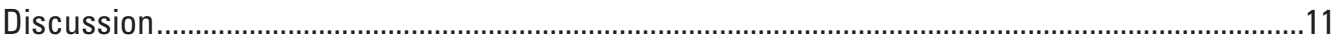

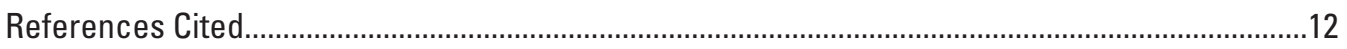

\section{Figures}

1. Map of U.S. Fish and Wildlife Service Conservation Zone 6 showing survey routes and marbled murrelet detections from Half Moon Bay to Santa Cruz, central California, 2019

2. Graph showing modeled detection probability of marbled murrelets sighted within perpendicular distance less than or equal to 0.12 kilometers of vessel for all surveys, U.S. Fish and Wildlife Service Conservation Zone 6, central California, 2019

3. Graph showing mean annual marbled murrelet at-sea abundance estimates, U.S. Fish and Wildlife Service Conservation Zone 6, central California, for all years for which survey data was available during 2001-19.

4. Graph showing date-corrected marbled murrelet hatch-year to after-hatch-year ratios, plus or minus standard errors, using standardized zig-zag surveys and all survey transect types, 1996-2019, U.S. Fish and Wildlife Service Conservation Zone 6, central California

\section{Tables}

1. Observer view condition classifications and descriptions for marbled murrelet surveys conducted from Half Moon Bay to Santa Cruz, central California, 2019

2. Marbled murrelet survey dates, route direction, effort, observations, and density/abundance estimates for all surveys, U.S. Fish and Wildlife Service Conservation Zone 6, central California, 2019.

3. Annual at-sea marbled murrelet abundance estimates and 95-percent confidence intervals for surveys drawn in both directions, surveys only drawn from the north, and surveys only drawn from the south, U.S. Fish and Wildlife Service Conservation Zone 6, central California, 1999-2019

4. Annual estimates of date-corrected hatch-year to after-hatch-year ratios and standard errors for marbled murrelets from at-sea surveys done during the breeding season using standardized zig-zag surveys and all survey transect types, U.S. Fish and Wildlife Service Conservation Zone 6, central California 


\section{Conversion Factors}

International System of Units to U.S. customary units

\begin{tabular}{|c|c|c|}
\hline Multiply & By & To obtain \\
\hline \multicolumn{3}{|c|}{ Length } \\
\hline meter $(\mathrm{m})$ & 3.281 & foot $(\mathrm{ft})$ \\
\hline kilometer $(\mathrm{km})$ & 0.6214 & mile (mi) \\
\hline meter (m) & 1.094 & yard (yd) \\
\hline \multicolumn{3}{|c|}{ Area } \\
\hline square kilometer $\left(\mathrm{km}^{2}\right)$ & 0.3861 & square mile $\left(\mathrm{mi}^{2}\right)$ \\
\hline \multicolumn{3}{|c|}{ U.S. customary units to International System of Units } \\
\hline Multiply & By & To obtain \\
\hline \multicolumn{3}{|c|}{ Speed } \\
\hline nautical mile per hour (knot) & 1.852 & kilometer per hour $(\mathrm{km} / \mathrm{h})$ \\
\hline
\end{tabular}

\section{Datum}

Horizontal coordinate information is referenced to the World Geodetic System of 1984 (WGS 84).

\section{Abbreviations}

$\chi^{2} \quad$ chi-squared

AHY after hatch year

df degrees of freedom

$\mathrm{Cl} \quad$ confidence interval

GPS Global Positioning System

HY hatch year

$\mathrm{N} \quad$ population estimate (number of birds)

n number of surveys

$P \quad$ probability value

$\mathrm{R} / \mathrm{V} \quad$ research vessel

SE standard error

USGS U.S. Geological Survey

WERC Western Ecological Research Center 


\title{
Abundance and Productivity of Marbled Murrelets (Brachyramphus marmoratus) Off Central California During the 2019 Breeding Season
}

\author{
By Jonathan J. Felis, Emily C. Kelsey, Josh Adams, Cheryl Horton, and Laney White
}

\section{Abstract}

Marbled murrelets (Brachyramphus marmoratus) have been listed as "endangered" by the State of California and "threatened" by the U.S. Fish and Wildlife Service since 1992 in California, Oregon, and Washington. Information regarding marbled murrelet abundance, distribution, population trends, and habitat associations is critical for risk assessment, effective management, evaluation of conservation efficacy, and ultimately, to meet Federal and State recovery efforts for this species. During June-August 2019, the U.S. Geological Survey Western Ecological Research Center continued previously established, long-term (1996-2019), at-sea surveys to estimate abundance and productivity of marbled murrelets in U.S. Fish and Wildlife Service Conservation Zone 6 (San Francisco Bay to Point Sur in central California). Using conventional distance sampling methods, we estimated marbled murrelet abundance using 125 detections of 216 murrelets (mean group size, 1.72) observed on 8 surveys. The abundance estimated for the entire study area using all surveys in 2019 was 404 birds (95-percent confidence interval, 272-601 birds). Estimated abundance from 2019 is comparable to most prior years of study. In 2019, we estimated reproductive productivity (calculated as the hatch-year [HY] to after-hatch-year [AHY] ratio) using three detections of three HY murrelets observed on six surveys.

After date-correcting HY and AHY counts to account for birds expected to be absent from the water while inland at nests, the date-corrected juvenile ratio was $0.025 \pm 0.020$ standard error. We discuss changes in methodologies during 1996-2019 that could be addressed in re-analysis of this long-term dataset. We updated a synthesized database of all Zone 6 marbled murrelet survey data since 1999 with 2019 data to allow scientists and managers to evaluate established survey methods and assess trends in abundance and productivity estimates.

\section{Introduction}

The marbled murrelet (Brachyramphus marmoratus) is a small, diving seabird of the family Alcidae. Marbled murrelets inhabit North American nearshore marine waters from Alaska to central California. In California, marbled murrelets nest from March to October in forests within 80 kilometers $(\mathrm{km})$ of the coast (Nelson, 1997). The southernmost known breeding area for marbled murrelets is south of San Francisco Bay in forested areas of the Santa Cruz Mountains near Point Año Nuevo and is separated from the nearest northern California population by 240-320 km. An estimated 174-699 murrelets compose the annual breeding population of marbled murrelets in this disjunct area (Henry, 2017). During their breeding season (April to August), the at-sea distribution of marbled murrelets extends primarily from Half Moon Bay to Santa Cruz, with greatest abundance in the waters near Point Año Nuevo (Henry, 2017). Sightings of marbled murrelets south of Santa Cruz in Monterey Bay during the breeding season are infrequent (Ralph and Miller, 1995; Henkel, 2004), but there has been less consistent survey effort in this region.

In 2019, the U.S. Geological Survey Western Ecological Research Center (USGS-WERC) partnered with California State Parks to continue long-term, at-sea surveys to estimate abundance and reproductive productivity of marbled murrelets in U.S. Fish and Wildlife Service Conservation Zone 6 (central California - San Francisco Bay to Point Sur). Marbled murrelets have been listed as "endangered" by the State of California and "threatened" by the U.S. Fish and Wildlife Service since 1992 in California, Oregon, and Washington. Abundance of marbled murrelets has been estimated at sea off central California since 1999 (excluding 2004-06; Henkel and Peery, 2008; Peery and others, 2009; Peery and Henry, 2010; Henry and others, 2012; Henry, 2017, Felis and others, 2018, Felis and others, 2019) and this monitoring program is funded by the U.S. Fish and Wildlife Service Natural Resource Damage Assessment and Restoration Program under the guidance of the Luckenbach Oil Spill Trustee Council. Information regarding marbled murrelet abundance, distribution, population trends, and habitat associations is critical for risk assessment, effective management and evaluation of conservation efficacy, and ultimately to meet Federal and State recovery efforts for this species. 
The USGS-WERC continued at-sea surveys in 2019 to assess abundance and productivity for two primary purposes: (1) to maintain efforts to quantify the status of marbled murrelets in central California (U.S. Fish and Wildlife Service Conservation Zone 6) and (2) to help evaluate potential benefits and marbled murrelet response to ongoing corvid control in coastal California State parks. Additionally, marbled murrelet distribution data at sea may help resource managers identify critical at-sea habitat for the species (for example, Bellefleur and others, 2009). In this report, we describe our methods and provide summaries of survey effort and results estimating marbled murrelet abundance and productivity (juvenile ratio) for 2019.

\section{Methods}

\section{At-Sea Survey Methods}

In 2019, USGS-WERC completed eight at-sea surveys for marbled murrelets between Half Moon Bay and Santa Cruz, California (fig. 1). We conducted surveys during the previously established survey window (June 1-August 24; Henry, 2017) and allocated surveys to two periods within this window: two surveys during June 1-July 9 and six surveys during July 10-August 24. Protocol dictates that three surveys are conducted in the first survey window and six in the second window (Henry, 2017), but in 2019 weather conditions prevented us from accomplishing all three surveys in the first window. We used data from all surveys to estimate marbled murrelet abundance, and we used the six surveys during the second survey period to estimate juvenile ratio (following Henry, 2017). Surveys were almost exclusively conducted when viewing conditions were excellent to good (table 1).

Historically, survey routes were designed as continuous, approximately $100-\mathrm{km}$ long zig-zag transect lines to sample nearshore (200-1,350 meters [m] from coast) and offshore
(1,350-2,500 $\mathrm{m}$ from coast) strata, with approximately four times greater effort within the nearshore stratum owing to greater known marbled murrelet densities nearshore (see Henry, 2017, and references therein). Routes originally were drawn starting at a random distance (200-2,500 m) from shore, and an equal number of routes were drawn using starting points at the north and south ends of the survey area. Survey routes that were drawn from the south resulted in a greater amount of habitat surveyed in south-facing, leeward bays that often had greater relative abundances of marbled murrelets than more exposed stretches of the coast (Henry, 2017).

In 2019, we identified 10 unique survey routes (5 each drawn from north and south) used by Henry (2017) during 2013-16 surveys and randomly selected our survey routes from this pool (without replacement) for each survey; ultimately, we used 8 survey routes ( 3 drawn from the north and 5 from the south) to complete the 8 surveys. We conducted all surveys by following the selected route from north (Pillar Point Harbor, Half Moon Bay) to south (Soquel Point, Monterey Bay) using a Global Positioning System (GPS). When the survey route intersected land or crossed hazardous areas (for example, high surf areas nearshore), we maintained survey effort while safely navigating as close as possible to the transect line. We conducted surveys from a small boat using line-transect methods (Becker and others, 1997; Peery and others, 2006; Henry, 2017). Two observers, standing on either side of a 6-m open skiff (R/V Lucy M) traveling 12-15 knots (22-28 km per hour), recorded the observation time, angle off the transect line, and the distance to all groups of marbled murrelets detected. The skiff was operated by a third crew member whose sole responsibility was piloting the vessel. Skiff size and travel speed were consistent with those used in surveys conducted since 2007. From 1999 to 2003, surveys were conducted in a 4-m open inflatable skiff at approximately 10 knots (18 km per hour).

Table 1. Observer view condition classifications and descriptions for marbled murrelet (Brachyramphus marmoratus) surveys conducted from Half Moon Bay to Santa Cruz, central California, 2019.

[ , approximately; $\mathrm{m}$, meter]

\begin{tabular}{ll}
$\begin{array}{c}\text { View } \\
\text { condition }\end{array}$ & \multicolumn{1}{c}{ Description } \\
\hline 5-Excellent & Glassy \\
4-Very Good & Wavelets and (or) minor glare \\
3 - Good & $\begin{array}{c}\text { Small waves/wavelets and (or) minor glare; still able to reliably detect murrelets within } \sim 150 \mathrm{~m} \text { of line (75 m aside for each } \\
\text { observer) }\end{array}$ \\
$\begin{array}{ll}\text { 2-Fair } & \text { Waves and (or) moderate glare; chance of missing murrelets within } \sim 150 \mathrm{~m} \text { of line (75 m aside for each observer) } \\
1 \text { - Poor } & \text { High wind waves and (or) high glare; murrelets very difficult to detect }\end{array}$ \\
\hline
\end{tabular}




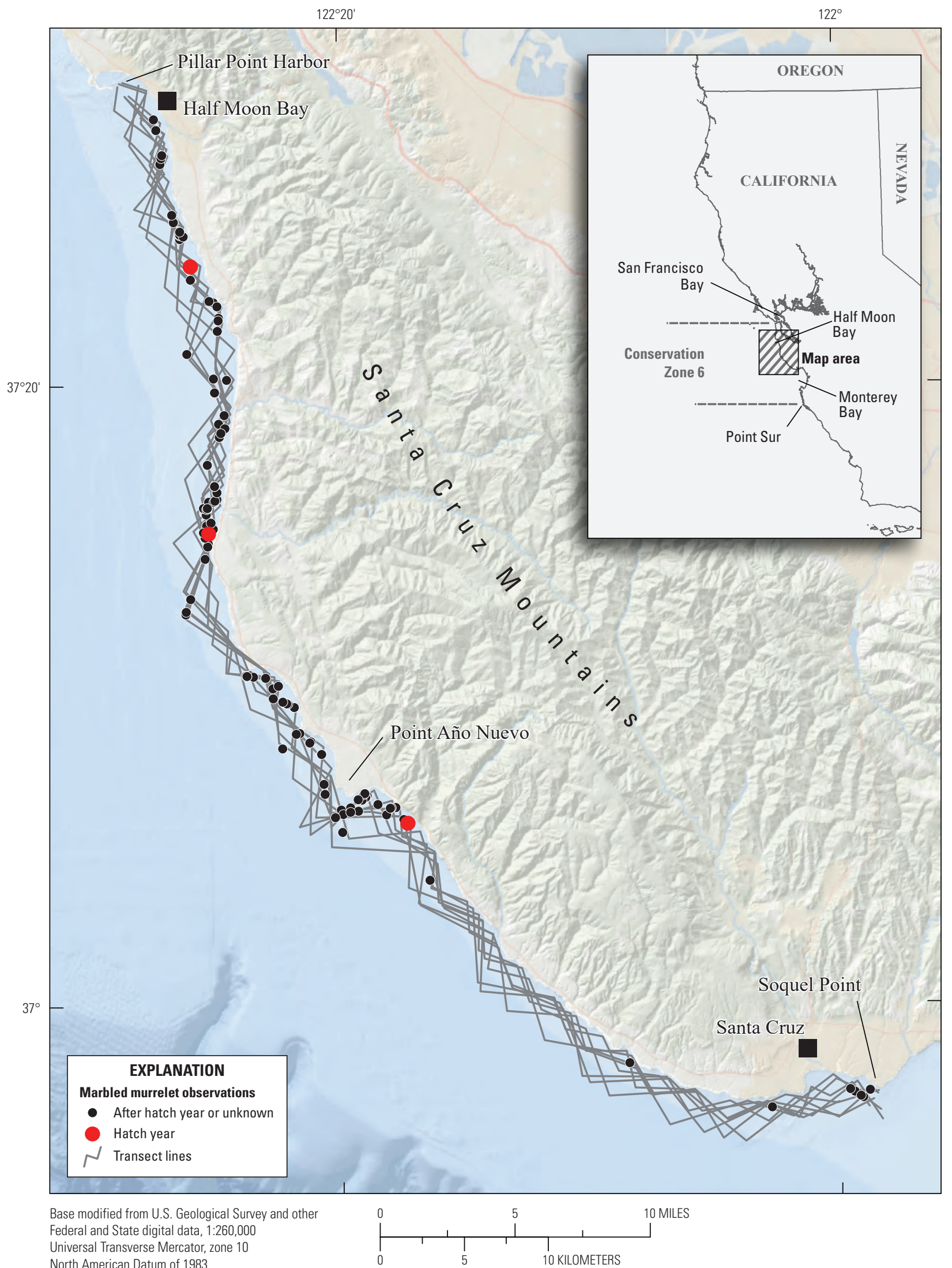

Figure 1. Survey routes and marbled murrelet (Brachyramphus marmoratus) detections from Half Moon Bay to Santa Cruz, central California, 2019. 
Observers counted marbled murrelets as a group when individuals were within $2 \mathrm{~m}$ of each other or if they showed behavior indicative of group status (for example, co-diving or vocalizing with one another; Strong and others, 1995). Observers recorded the age-class of each marbled murrelet based on three plumage classifications: (1) "after-hatch-year" (AHY), (2) "hatch-year" (HY), or (3) "unknown." Behavior was recorded as "resting" on the water or "flying," with flight direction noted. Distance and angle were estimated at the time of first detection, regardless of behavior. Prior to each survey, observers calibrated distance estimation using a laser rangefinder on buoys and other targets in the harbor. To facilitate estimations of sighting angles, we placed marks along the bow of the boat in 10-degree increments. The vessel occasionally paused or deviated from the transect line to properly identify marbled murrelet age-class; no additional observations were counted during these deviations. Observers also recorded observations of all non-murrelet marine birds and mammals encountered along transects, consistent with surveys conducted since 2007. Marine mammal observations were recorded using line-transect methods as described for murrelets and non-murrelet bird observations were counted in a 75-m aside strip transect (no distances or angles recorded). Non-murrelet observations were archived but are not presented or analyzed in this report.

Observers recorded all observations and observation times using digital voice recorders, including survey start and end times, ocean conditions (Beaufort Sea state), viewing conditions (table 1), and time periods when effort was paused for any reason (for example, vessel deviated from the transect line to identify marbled murrelet age-class). Observers reviewed their own recordings and transcribed and tabulated their sighting data into a single spreadsheet that was examined for quality assurance and quality control and then merged into a combined spreadsheet. We acquired a continuous 1-second GPS track during each survey using a handheld GPS unit; this track was used to georeference observations based on matching date/time using custom scripting in R (R Core Team, 2016).

We updated a synthesized database of all marbled murrelet survey data since 1999 (Felis and others, 2020) with 2019 data to allow scientists and managers to evaluate established survey methods and assess trends in abundance estimation and juvenile ratios.

\section{Abundance Estimation Methods}

We calculated perpendicular distance for each detection (sine of the sighting angle $\times$ observation distance) and inspected the distribution of perpendicular detection distances to select a truncation distance where detections approached zero, beyond which we excluded observations from analysis. Consistent with previous years, we included sightings of flying birds in our analysis, despite the potential that flying birds likely have a different probability of detection and including these could affect abundance estimates. Historical protocol for this monitoring program indicates that flying birds should only be counted if they cross the beam of the vessel (Henry and Tyler, 2017). Additionally, the distance and angle to flying birds was only estimated when flying birds actually crossed the beam (90-degree angle and a distance estimate) in earlier years (1999-2003). In later years, re-examination of historical data (Felis and others, 2019) shows that flying birds, assuming they were only counted if they crossed the beam, were given a distance/angle estimate for when they were first detected. We maintained the methodology of 2007-19 for estimating distance and angle of flying birds.

We created a spatial representation of strata in ArcGISTM based on the same coastline shapefile used in 2007-18 (California Department of Fish and Wildlife, 2004) and calculated linear effort for each survey within each stratum consistent with previous years by using the hypothetical survey route delineated by the zigzag segment nodes (table 2). We assigned marbled murrelet observations to either the nearshore or offshore stratum in ArcGISTM based on spatial overlap. The calculation of stratum-specific linear effort and the assignment of observations to strata from 1999 to 2003 was done with an older coastline representation (Peery and others, 2006). We maintained the use of the modern stratum delineation to facilitate comparison of our abundance estimates to recent data (2007-19) but advise caution when comparing to older abundance estimates from 1999 to 2003.

Following Henry (2017), we used the program DISTANCE v7.1 (Thomas and others, 2010) to model our detection function and estimate marbled murrelet abundance using conventional distance sampling (see Buckland and others, 2015, for detection function modeling, model selection, and line transect abundance estimation methods). Specifically, using DISTANCE v7.1, we pooled observations from all 2019 surveys to create a global detection function for 2019 surveys and applied this function to each survey to calculate stratum- and survey-specific density estimates based on the linear effort sampled during each survey. Consistent with Henry (2017), we grouped perpendicular detection distances into $20-\mathrm{m}$ bins, used a $120-\mathrm{m}$ truncation distance, and evaluated the half-normal function, with or without cosine expansion; we selected the detection function with the smallest Akaike information criterion (AIC; Burnham and Anderson, 2004) value (that is, most parsimonious fit). We used the mean of observed cluster size method to estimate cluster (group) sizes at the sample (observation) level. We calculated survey-specific abundances by multiplying the stratum-specific density estimate by the total area of each stratum in the study area (104.65 square kilometers $\left[\mathrm{km}^{2}\right]$ for each) and then summed the two stratum-specific abundance values for a total area abundance estimate. Consistent with Henry (2017), we repeated the analysis described above with the data partitioned by survey route draw-direction to evaluate the effect of survey route draw-direction on abundance estimation. New, direction-specific detection functions were modeled for these subsets of the data and used to estimate abundance (following Henry, 2017). 
Table 2. Marbled murrelet (Brachyramphus marmoratus) survey dates, route direction, effort, observations, and density/abundance estimates for all surveys, U.S. Fish and Wildlife Service Conservation Zone 6, central California, 2019.

[mm/dd/yyyy, month/day/year; km, kilometer; km², square kilometer; \%, percent; CI, confidence interval; USGS, U.S. Geological Survey]

\begin{tabular}{|c|c|c|c|c|c|c|c|c|c|}
\hline $\begin{array}{c}\text { Survey date } \\
\text { (mm/dd/ } \\
\text { yyyy) }\end{array}$ & $\begin{array}{c}\text { Route } \\
\text { direction }\end{array}$ & $\begin{array}{l}\text { Transect } \\
\text { length } \\
(\mathbf{k m})\end{array}$ & $\begin{array}{c}\text { Number } \\
\text { of } \\
\text { groups }\end{array}$ & $\begin{array}{l}\text { Mean } \\
\text { group } \\
\text { size }\end{array}$ & $\begin{array}{c}\begin{array}{c}\text { Number } \\
\text { of } \\
\text { individuals }\end{array} \\
\text { inidu }\end{array}$ & $\begin{array}{c}\text { Number } \\
\text { of hatch } \\
\text { year }\end{array}$ & $\begin{array}{l}\text { Nearshore density } \\
\text { birds per km² } \\
(95 \% \mathrm{Cl})\end{array}$ & $\begin{array}{l}\text { Offshore density } \\
\text { birds per km² } \\
\text { (95\% Cl) }\end{array}$ & $\begin{array}{l}\text { Abundance } \\
\text { birds } \\
(95 \% \text { Cl) }\end{array}$ \\
\hline 06/12/2019 & South & 97.3 & 9 & 2.00 & 18 & 0 & $2.25(1.37-3.69)$ & 0.00 & $235(143-386)$ \\
\hline 06/14/2019 & North & 103.9 & 14 & 1.71 & 24 & 0 & $2.87(2.10-3.94)$ & 0.00 & $300(220-412)$ \\
\hline 07/18/2019 & South & 96.5 & 22 & 1.36 & 30 & 0 & $3.66(2.80-4.78)$ & $0.91(0.73-1.13)$ & 478 (369-618) \\
\hline 07/22/2019 & North & 103.7 & 27 & 1.85 & 50 & 0 & $5.45(4.16-7.14)$ & $2.62(0.63-10.82)$ & $845(501-1880)$ \\
\hline 08/09/2019 & South & 95.7 & 22 & 1.81 & 40 & 1 & $5.13(4.02-6.56)$ & 0.00 & $537(421-687)$ \\
\hline 08/10/2019 & North & 101.7 & 10 & 1.70 & 17 & 0 & $1.69(1.26-2.26)$ & $1.44(0.09-24.30)$ & $328(141-2780)$ \\
\hline 08/15/2019 & South & 101.1 & 8 & 1.86 & 15 & 2 & $1.85(1.23-2.77)$ & 0.00 & $194(129-290)$ \\
\hline 08/19/2019 & South & 101.6 & 13 & 1.69 & 22 & 0 & $2.69(2.06-3.52)$ & 0.00 & $282(216-368)$ \\
\hline
\end{tabular}

We report annual abundances and 95-percent confidence intervals (95-percent CI) estimates for 2017-19 (current program of study), and historical abundance estimates from 1999 to 2016 (as reported by Henry 2017). Historical estimates were calculated similarly, with a few exceptions. The modeling of detection functions allowed for the inclusion of covariates (observer, view conditions) in annual model selection from 1999 to 2003, but not during following years (Peery and others, 2006). Additionally, detection functions were modeled annually except for 2008, when at-sea murrelet observations and number of surveys were too few to model a year-specific detection function. As a result, a detection function was modeled using pooled observation data from 2007 to 2008 and applied to 2008 data to estimate abundance (Peery and others, 2008). Finally, the spatial boundaries of strata are different for 1999-2003 and 2007-19 analyses.

\section{Juvenile Ratio Estimation Methods}

We estimated the juvenile ratio (the ratio of $\mathrm{HY}$ to AHY individuals) for marbled murrelet surveys conducted during the fledging period. The previously established fledging period ranged from July 10, when an estimated 34 percent of HY birds are thought to have fledged, to August 24, about the time when $\mathrm{HY}$ and AHY murrelets become indistinguishable at sea because AHY birds begin pre-basic molt (Long and others, 2001; Peery and others, 2007). Thus, we included only surveys between July 10 and August 24 to estimate the 2019 juvenile ratio (following Henry, 2017). Identification of HY birds followed techniques outlined by Long and others (2001) and were aided by reviewing photographs and resources provided by the Alaska murrelet group (K. Nesvacil, Alaska Department of Fish and Game, written commun., 2017) before surveys. We included only those birds confidently identified to age class to estimate the juvenile ratio.
We adjusted HY and AHY counts to account for birds estimated to have been inland during the time of the survey. A certain percentage of AHY birds are still incubating young during the fledging period and, therefore, are not on the water during at-sea surveys, potentially creating a positively biased juvenile ratio. The proportion of AHY birds incubating is reported to be less than 6 percent between July 10 and July 17 and less than 1 percent after July 17 (Peery and others, 2004, 2007). Therefore, to correct for the number of AHY birds counted at sea between July 10 and July 17, we calculated, as the date-corrected number of AHY individuals:

$$
A_{\text {corrected }}=\frac{A_{\text {observed }}}{1-\left(\begin{array}{l}
18.7145545-0.18445455 \times \\
D^{\prime} A E_{i}+0.00045455 \times D A T E_{i}^{2}
\end{array}\right)}
$$

where

$A_{\text {observed }}$ is the number of after-hatch-year (AHY) birds counted on survey $i$, and

the denominator is 1 minus the linear regression model for the proportion of incubating AHY individuals estimated for the Julian Day of survey $i\left(D A T E_{i}\right.$; Peery and others, 2007).

For surveys after July 17, we assumed no birds were incubating, and the observed number of AHY birds was not corrected.

In addition to adjusting for incubating adults (to avoid positive bias in the estimated ratio), the juvenile ratio calculation can be negatively biased by not accounting for HY birds that have not yet fledged by the time of the survey. Based on 47 observed fledging events in California, Peery and others (2007) estimated that 75 percent of juveniles had fledged by August 24, considered herein to be the last day of the fledging period. Therefore, to adjust for the number of HY birds observed during a given at-sea survey, we calculated $H_{\text {corrected }}$ after Peery and others (2007): 


$$
H_{\text {corrected }}=\frac{H_{\text {observed }}}{-1.5433+0.0098 \times D A T E_{i}}
$$

where

$$
\begin{gathered}
H_{\text {corrected }} \text { is the date-corrected number of hatch-year } \\
\text { (HY) individuals, } \\
H_{\text {observed }} \text { is the number of HY individuals counted on } \\
\text { survey } i \text {, and }
\end{gathered}
$$

the denominator is the regression model for the cumulative proportion of HY birds fledged, predicted according to Julian Day $\left(D_{A T E}\right)$.

We used $A_{\text {corrected }}$ and $H_{\text {corrected }}$ to estimate the juvenile ratio $\left(\widehat{R}_{t}\right)$ for year $t$,

$$
\widehat{R}_{t}=\frac{\sum{ }^{q} H_{i}}{\sum \mu_{i}}
$$

where

$$
\begin{gathered}
H_{i} \text { and } A_{i} \quad \begin{array}{l}
\text { are the number of hatch-year and } \\
\text { after-hatch-year individuals for survey } i, \\
\text { respectively, and }
\end{array} \\
\quad \begin{array}{l}
\text { is the number of surveys done in year } t \text { (Levy } \\
\text { and Lemeshow, 1991). }
\end{array}
\end{gathered}
$$

We estimated the variance of the juvenile ratio $\left(v \hat{a} r\left(\widehat{H}_{t}\right)\right)$ as

$$
\operatorname{var} r\left(\widehat{R}_{t}\right)=\frac{1}{n}\left(\frac{\operatorname{va} r\left(\widehat{H}_{t}\right)}{\widehat{A}_{t}^{2}}+\frac{\widehat{H}_{t}^{2} v a \hat{r} r\left(\widehat{A}_{t}\right)}{\widehat{A}_{t}^{4}}-\frac{2 \widehat{H}_{t} \operatorname{co} v\left(\widehat{H}_{t} \widehat{A}_{t}\right)}{\widehat{A}_{t}^{3}}\right)
$$

where

$$
\begin{array}{r}
\operatorname{var}\left(\widehat{H}_{t}\right) \quad \begin{array}{l}
\text { is the variance in the number of hatch-year } \\
(\mathrm{HY}) \text { individuals observed in year } t,
\end{array}
\end{array}
$$

$\operatorname{var}\left(\widehat{A}_{t}\right) \quad$ is the variance in the number of after-hatch-year (AHY) individuals observed in year $t$,

$\operatorname{co} v\left(\widehat{A}_{t}, \widehat{H}_{t}\right) \quad$ is the covariance between the numbers of HY and AHY individuals observed in year $t$, and

$\widehat{H}_{t}$ and $\widehat{A}_{t} \quad$ are the mean number of HY and AHY individuals observed in year $t$, respectively (van Kempen and van Vliet, 2000; Peery and others, 2007; Henry, 2017).

In past annual reports, we included juvenile ratios from 1996 to 2016 as reported by Henry (2017; prior to USGS surveys) with our results (Felis and others, 2018; Felis and others, 2019). However, these pre-2017 results were obtained using various survey transect designs. Surveys used for juvenile estimates followed (1) shore-parallel transects (400-m from shore) from Half Moon Bay to Soquel Point for 1996-98, (2) standardized zig-zag transects for 2001-11 and 2014-19 (a subset of the abundance estimation transects), or (3) a combination of (1) and (2) for 1999-2000 and 2012-13
(Henry, 2017; Peery and others, 2007). Because changes in sampling design and area of inference during the course of this program could complicate interannual comparison, we recalculated annual juvenile ratios for 1999-2000 and 2012-13 using only standardized zig-zag transects (using data compiled in Felis and others, 2020) and report those results here in addition to historical estimates. We did all calculations to estimate juvenile ratios (uncorrected and corrected) and associated variance using R (R Core Team, 2016).

\section{Marbled Murrelet Abundance and Productivity Results}

\section{Abundance Estimation Results}

We detected 131 marbled murrelet groups consisting of 225 murrelets on all surveys combined in 2019. Murrelet sightings were concentrated around Point Año Nuevo. Sightings were sporadic between Half Moon Bay and Point Año Nuevo and infrequent between Point Año Nuevo and Santa Cruz (fig. 1). Detections approached zero at $120 \mathrm{~m}$ horizontal sighting distance; therefore, consistent with Henry (2017), we excluded from analysis observations that were greater than $120 \mathrm{~m}$ from the transect line. We included flying birds (10 percent of all detections less than or equal to $120 \mathrm{~m}$ from the transect line; following Henry, 2017). After removing 5 detections greater than $120 \mathrm{~m}$ and 1 detection with no specified distance, we estimated marbled murrelet abundance using 125 detections of 216 murrelets (mean group size, 1.72; table 2; fig. 1).

For all surveys combined (regardless of draw direction), the half-normal detection model with a cosine adjustment (order 2) was the best-fitting model, and the observed number of sightings was not significantly different from the number predicted using this detection model (chi-squared $\left[\chi^{2}\right]=2.69$, degrees of freedom $[\mathrm{df}]=3$, probability value $[P]=0.44$; fig. 2). Survey-specific marbled murrelet density estimates ranged from 1.69 to 5.45 birds per $\mathrm{km}^{2}$ in the nearshore stratum and from 0.00 to 2.62 birds per $\mathrm{km}^{2}$ in the offshore stratum; survey-specific abundance estimates ranged from 194 to 845 murrelets (table 2). The abundance estimated for the entire study area in 2019 using all surveys was 404 murrelets (95-percent CI, 272-601 murrelets; percent coefficient of variation [CV], 19.48; table 3). The half-normal detection models with no cosine adjustments were the best-fitting model for north-drawn surveys $\left(\chi^{2}=2.90, \mathrm{df}=4, P=0.58\right)$ and south-drawn surveys $\left(\chi^{2}=7.95, \mathrm{df}=4, P=0.09\right)$. Estimated abundance for surveys drawn from the north (446 murrelets; 95-percent CI, 204-971 murrelets) was more than for surveys drawn from the south (288 murrelets; 95-percent CI, 178-467 murrelets; table 3), although the estimates overlapped at the 95-percent confidence-level. Estimated abundances for all study years (2001-19) are shown in table 3 and figure 3. 


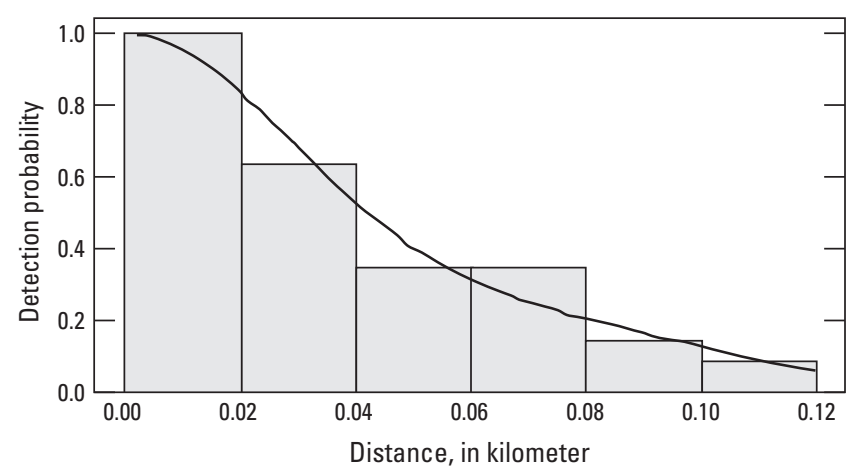

Figure 2. Modeled detection probability of marbled murrelets (Brachyramphus marmoratus) sighted within perpendicular distance less than or equal to 0.12 kilometers of vessel for all surveys, U.S. Fish and Wildlife Service Conservation Zone 6, central California, 2019. Bin width is 0.02 kilometers.

Table 3. Annual at-sea marbled murrelet (Brachyramphus marmoratus) abundance estimates $(M)$ and 95-percent confidence intervals (CI) for surveys drawn in both directions, surveys only drawn from the north, and surveys only drawn from the south, U.S. Fish and Wildlife Service Conservation Zone 6, central California, 1999-2019.

[Number of surveys, $n$, used in each estimate is listed. Abbreviations: \%, percent; CI, confidence interval; —, no data; N/A, not applicable]

\begin{tabular}{|c|c|c|c|c|c|c|c|c|c|}
\hline \multirow[b]{2}{*}{ Year } & \multicolumn{3}{|c|}{ Both Directions } & \multicolumn{3}{|c|}{ North } & \multicolumn{3}{|c|}{ South } \\
\hline & $\boldsymbol{N}$ & $95 \% \mathrm{Cl}$ & $n$ & $\mathbf{N}$ & $95 \% \mathrm{Cl}$ & $n$ & $\boldsymbol{N}$ & $95 \% \mathrm{Cl}$ & $N$ \\
\hline 1999 & - & N/A & - & 487 & $333-713$ & 5 & - & no surveys & - \\
\hline 2001 & 661 & $556-786$ & 15 & 637 & $441-920$ & 8 & 733 & $583-922$ & 7 \\
\hline 2002 & 683 & $561-832$ & 15 & 628 & $487-809$ & 9 & 729 & $494-1075$ & 6 \\
\hline 2005 & - & No surveys & - & - & No surveys & - & - & No surveys & - \\
\hline 2006 & - & No surveys & & & No surveys & & & No surveys & \\
\hline 2007 & 378 & $238-518$ & 4 & 269 & $109-429$ & 2 & 488 & $349-626$ & 2 \\
\hline 2008 & 174 & $91-256$ & 4 & 122 & $61-184$ & 1 & 225 & $131-319$ & 3 \\
\hline 2012 & 487 & $403-588$ & 6 & 475 & $373-605$ & 3 & 501 & $359-699$ & 3 \\
\hline 2013 & 628 & $386-1022$ & 6 & 439 & $233-827$ & 3 & 556 & $126-2456$ & 3 \\
\hline 2014 & 438 & $307-624$ & 9 & 444 & $258-765$ & 4 & 434 & $231-817$ & 4 \\
\hline 2015 & 243 & $152-386$ & 9 & 225 & $136-370$ & 4 & 296 & $159-549$ & 5 \\
\hline 2016 & 657 & $406-1063$ & 7 & 510 & $358-726$ & 3 & 720 & $297-1747$ & 4 \\
\hline 2017 & 530 & $384-732$ & 9 & 413 & $247-689$ & 4 & 790 & $487-1280$ & 5 \\
\hline 2018 & 370 & $250-546$ & 9 & 513 & $334-788$ & 4 & 227 & $112-460$ & 5 \\
\hline 2019 & 404 & $272-601$ & 8 & 446 & 204-971 & 3 & 288 & $178-467$ & 5 \\
\hline
\end{tabular}




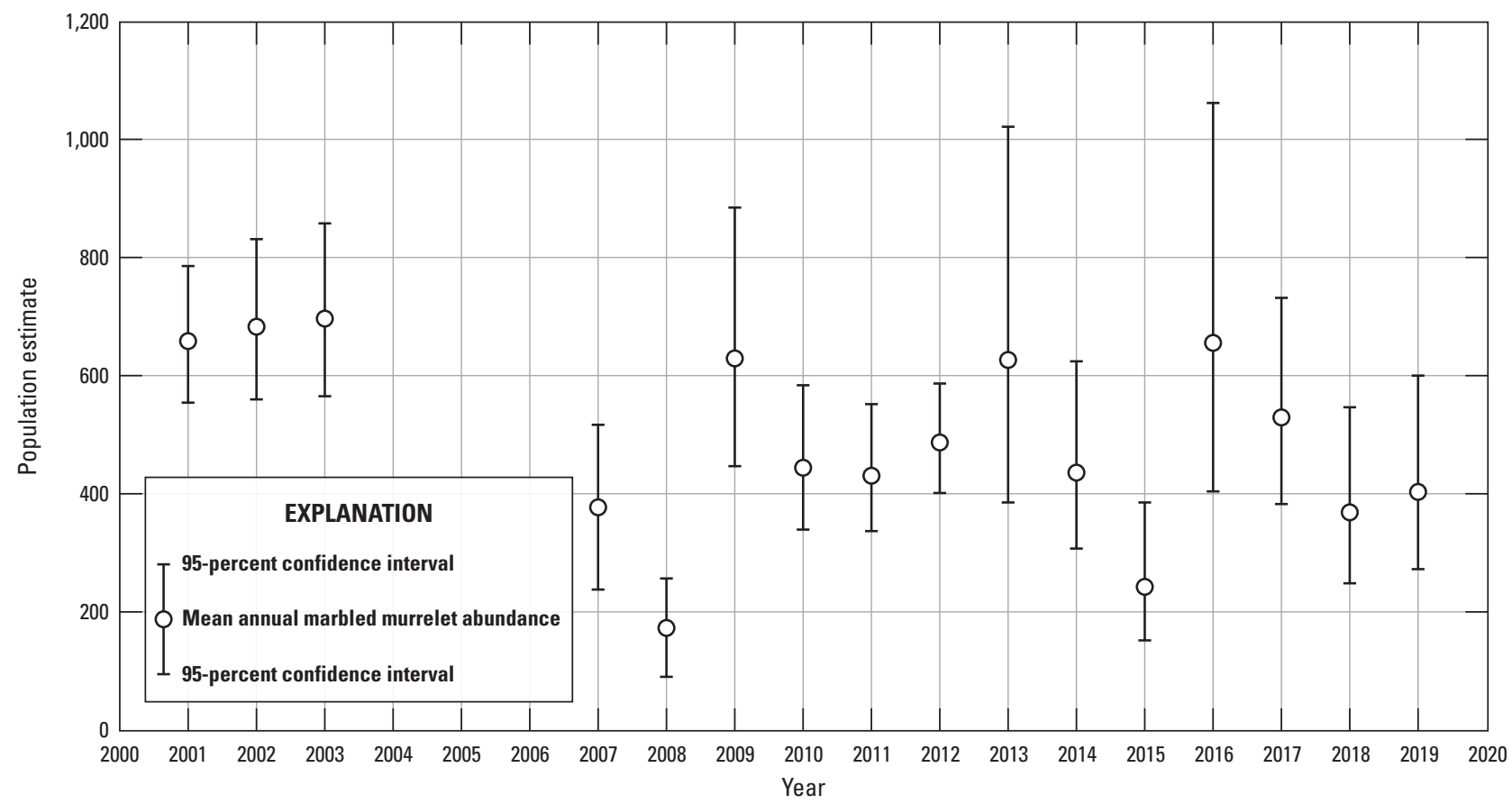

Figure 3. Mean annual marbled murrelet (Brachyramphus marmoratus) at-sea abundance estimates, U.S. Fish and Wildlife Service Conservation Zone 6, central California, for all years for which survey data was available during 2001-19. Years 1999 and 2000 are excluded because survey routes were only drawn from the north in those years, and no surveys were conducted in 2004-06. All values from years prior to 2017 were referenced from Henry (2017). 


\section{Productivity—Juvenile Ratio Results}

We detected three HY marbled murrelets in 2019: one on August 9, and two on August 15 (table 2; fig. 1). In 2019, the uncorrected juvenile ratio $(R)$ was $=0.017 \pm 0.013$ standard error (SE), and the corrected juvenile ratio $(\widehat{R})$ was
$0.025 \pm 0.020$ SE. Estimated corrected juvenile ratios using standardized zig-zag surveys (1999-2019; calculated in this study) and all transect types (shore-parallel, 1996-98; a combination of zig-zag and shore-parallel, 1999-2000, 2012-13; as reported by Henry, 2017) are shown in table 4 and figure 4.

Table 4. Annual estimates of date-corrected hatch-year to after-hatch-year ratios $(\widehat{R})$ and standard errors (SE) for marbled murrelets (Brachyramphus marmoratus) from at-sea surveys done during the breeding season using standardized zig-zag surveys (1999-2019; calculated in this study) and all survey transect types (shore-parallel, 1996-98; a combination of zig-zag and shore-parallel, 1999-2000, 2012-13; zig-zag only, 2001-11, 2014-16; as reported by Henry, 2017), U.S. Fish and Wildlife Service Conservation Zone 6, central California.

[Note that values are identical in years where only zig-zag surveys were conducted. No surveys were conducted in 2004-06. Number of surveys, $n$, used in each estimate is listed. Surveys used to estimate ratios were limited to July 10-August 24. Date-corrected estimates were corrected for the proportion of hatch-year murrelets that had not fledged and the proportion of after-hatch-year murrelets still incubating at the time the survey was done (see Peery and others, 2007). Abbreviation: NA, not applicable; +, plus]

\begin{tabular}{|c|c|c|c|c|c|c|c|}
\hline \multirow{2}{*}{ Year } & \multirow{2}{*}{$\begin{array}{c}\text { Survey types } \\
\text { conducted }\end{array}$} & \multicolumn{3}{|c|}{ All survey types (historically reported) } & \multicolumn{3}{|c|}{ Zig-zag only (calculated in this study } \\
\hline & & $n$ & $\widehat{\boldsymbol{R}}$ & SE & $n$ & $\widehat{\boldsymbol{R}}$ & SE \\
\hline 1996 & Parallel & 4 & 0.010 & 0.003 & 0 & NA & NA \\
\hline 1997 & Parallel & 5 & 0.022 & 0.007 & 0 & NA & NA \\
\hline 1998 & Parallel & 6 & 0.013 & 0.006 & 0 & NA & NA \\
\hline 1999 & Zig+parallel & 10 & 0.033 & 0.010 & 4 & 0.057 & 0.027 \\
\hline 2000 & Zig+parallel & 9 & 0.049 & 0.016 & 4 & 0.024 & 0.012 \\
\hline 2001 & Zig & 8 & 0.070 & 0.021 & 8 & 0.070 & 0.021 \\
\hline 2002 & Zig & 11 & 0.051 & 0.009 & 11 & 0.051 & 0.009 \\
\hline 2003 & Zig & 8 & 0.049 & 0.011 & 8 & 0.049 & 0.011 \\
\hline 2004 & No surveys & 0 & \multicolumn{2}{|c|}{ No surveys } & 0 & \multicolumn{2}{|c|}{ No surveys } \\
\hline 2005 & No surveys & 0 & \multicolumn{2}{|c|}{ No surveys } & 0 & \multicolumn{2}{|c|}{ No surveys } \\
\hline 2006 & No surveys & 0 & \multicolumn{2}{|c|}{ No surveys } & 0 & \multicolumn{2}{|c|}{ No surveys } \\
\hline 2007 & Zig & 3 & 0.049 & 0.052 & 3 & 0.049 & 0.052 \\
\hline 2008 & Zig & 4 & 0.000 & NA & 4 & 0.000 & NA \\
\hline 2009 & Zig & 4 & 0.028 & 0.018 & 4 & 0.028 & 0.018 \\
\hline 2010 & Zig & 3 & 0.081 & 0.039 & 3 & 0.081 & 0.039 \\
\hline 2011 & Zig & 3 & 0.080 & 0.018 & 3 & 0.080 & 0.018 \\
\hline 2012 & Zig+parallel & 5 & 0.032 & 0.019 & 3 & 0.029 & 0.022 \\
\hline 2013 & Zig+parallel & 6 & 0.093 & 0.025 & 3 & 0.122 & 0.062 \\
\hline 2014 & Zig & 6 & 0.081 & 0.035 & 6 & 0.081 & 0.035 \\
\hline 2015 & Zig & 6 & 0.059 & 0.020 & 6 & 0.059 & 0.020 \\
\hline 2016 & Zig & 5 & 0.108 & 0.051 & 5 & 0.108 & 0.051 \\
\hline 2017 & Zig & 6 & 0.022 & 0.015 & 6 & 0.022 & 0.015 \\
\hline 2018 & Zig & 6 & 0.047 & 0.032 & 6 & 0.047 & 0.032 \\
\hline 2019 & Zig & 6 & 0.025 & 0.020 & 6 & 0.025 & 0.020 \\
\hline
\end{tabular}




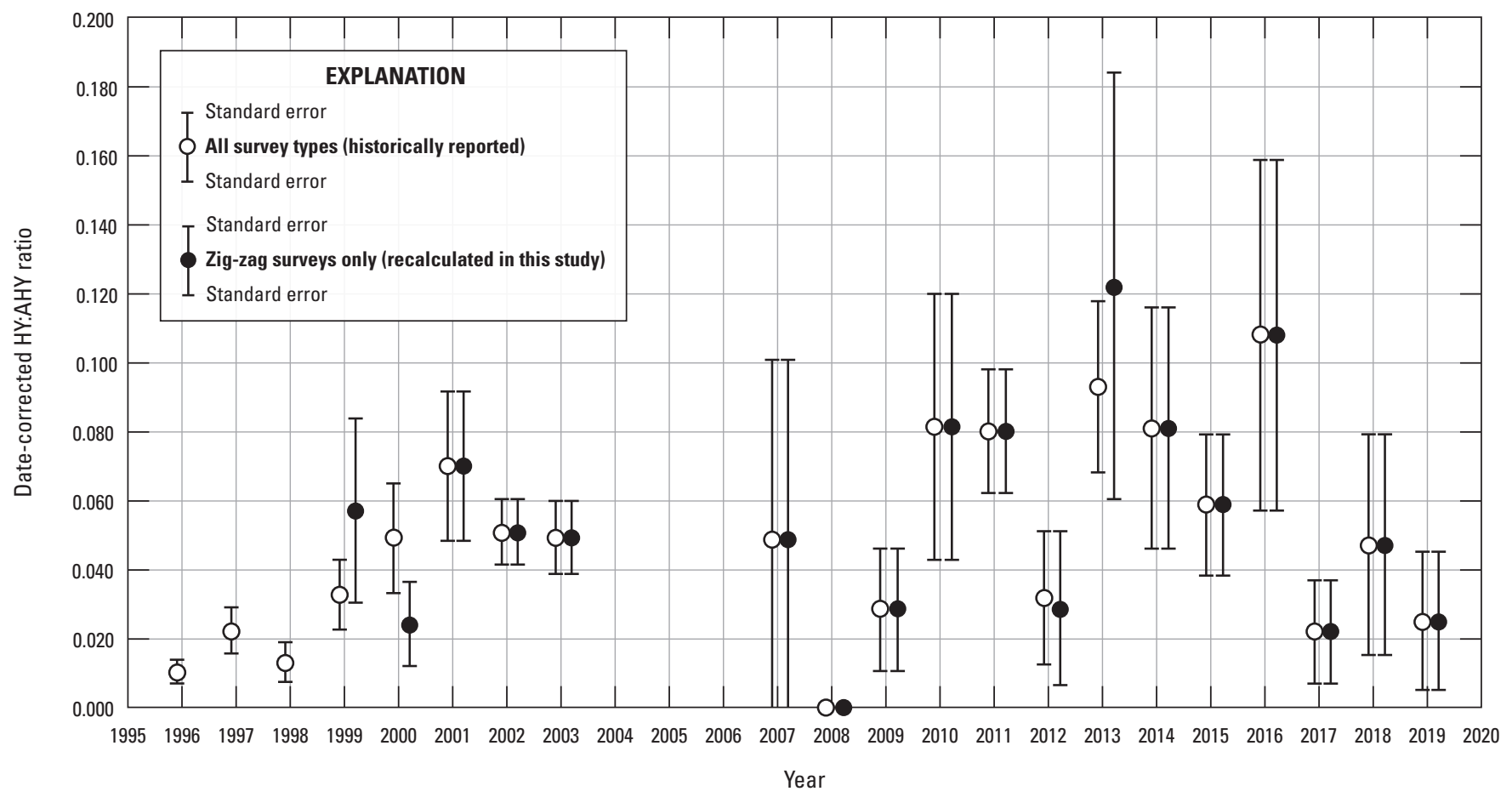

Figure 4. Date-corrected marbled murrelet (Brachyramphus marmoratus) hatch-year to after-hatch-year ratios, plus or minus standard errors, U.S. Fish and Wildlife Service Conservation Zone 6, central California, using standardized zig-zag surveys (black markers; 1999-2019; calculated in this study) and all survey transect types (hollow markers; shore-parallel, 1996-98; a combination of zig-zag and shore-parallel, 1999-2000, 2012-13; zig-zag, 2001-11, 2014-19; as reported by Henry, 2017). Note that values are identical in years where only zig-zag surveys were conducted. No surveys were conducted in 2004-06. Surveys used to estimate ratios were limited to July 10-August 24. Date-corrected estimates were corrected for the proportion of hatch-year murrelets that had not fledged and the proportion of after-hatch-year murrelets still incubating at the time the survey was done (see Peery and others, 2007). 


\section{Discussion}

We followed survey methods and analytical procedures to estimate densities and abundances for marbled murrelets using conventional distance sampling off central California according to methods described in Henry (2017). Estimated abundance from 2019 was below the long-term mean (2001-19: 491 murrelets) but is comparable at the 95-percent CI level to most prior years of study. Comparison is challenged by changes in methodologies over time. Future re-calculation of annual abundance estimates could (1) model more robust global detection functions for distinct eras of this program (for example, 1999-2003 with a smaller vessel at slower speeds and 2007-19 with a larger vessel at faster speeds); (2) consistently allow for covariates (for example, observer, viewing conditions) to be included in detection function modeling; (3) remove flying birds from detection function modeling and potentially from annual density and abundance estimates because of the inconsistencies in how and when these birds were recorded over time; and (4) use consistent stratum boundaries to assign linear effort and observations to the nearshore and offshore strata.

The corrected juvenile ratio in 2019 (0.025) was less than the long-term mean from zig-zag surveys (1999-2019: 0.055) and for all survey types combined (1996-2019: 0.048). Using corrected juvenile ratios from all survey types combined, Henry (2017) suggested that productivity had increased during 1996-2016. The re-calculation of corrected juvenile ratios using comparable sampling methods (limited to zig-zag surveys, 1999-2019) revealed no clear patterns in productivity over time, although formal statistical analysis is warranted. Both inter-annual variability in juvenile ratio estimates and the variance around those ratios appeared to increase between earlier (1996-2003) and later (2007-19) study years, for unknown reasons. Future annual productivity estimates and analysis of trend could further investigate (1) changes in survey platform (for example, 1996-2003 with a smaller vessel at slower speeds, 2007-19 with a larger vessel at faster speeds) and (2) changes in transect design, wherein shore-parallel transects (400 m from coast; 1996-2000) sample areas of much greater murrelet density (Becker and others, 1997) than zig-zag transects (2001-19).

Future work of analyzing these annual abundance and productivity estimates for trend, as well as power to detect trend, could provide useful information for evaluating the effectiveness of this monitoring program. The annual marbled murrelet survey program has involved several different research groups through time; therefore, we updated a synthesized database of all marbled murrelet survey data since 1999 with 2019 data to allow scientists and managers to evaluate established survey methods and assess trends in abundance estimation and juvenile ratios (Felis and others, 2020). This database also facilitates annual survey logistics (for example, pre-survey planning) and promotes repeatability of analytical methods across years and project teams. 


\section{References Cited}

Becker, B.H., Beissinger, S.R., and Carter, H.R., 1997, At-sea density monitoring of marbled murrelets in central California-Methodological considerations: The Condor, v. 99, no. 3, p. 743-755, https://doi.org/10.2307/1370485.

Bellefleur, D., Lee, P., and Ronconi, R.A., 2009, The impact of recreational boat traffic on Marbled Murrelets (Brachyramphus marmoratus): Journal of Environmental Management, v. 90, no. 1, p. 531-538, https://doi.org/ 10.1016/j.jenvman.2007.12.002.

Buckland, S.T., Rexstad, E.A., Marques, T.A., and Oedekoven, C.S., 2015, Distance sampling-Methods and applications: Cham, Switzerland, Springer International Publishing, 277 p., https://doi.org/10.1007/978-3-31919219-2.

Burnham, K.P., and Anderson, D.R., 2004, Multimodel inference-Understanding AIC and BIC in model selection: Sociological Methods \& Research, v. 33, no. 2, p. 261-304, https://doi.org/10.1177/0049124104268644.

California Department of Fish and Wildlife, 2004, Generalized California coastline - coastn83.shp: California Department of Fish and Wildlife database, accessed October 20, 2017, at https://www.wildlife.ca.gov/Conservation/Marine/GIS/ Downloads.

Felis, J.J., Adams, J., and Kelsey, E.C., 2018, Abundance and productivity of marbled murrelets (Brachyramphus marmoratus) off central California during the 2017 breeding season: U.S. Geological Survey Data Series 1093, 12 p., https://doi.org/10.3133/ds1093.

Felis, J.J., Adams, J., Peery, M.Z., Henry, R.W., Henkel, L.A., Becker, B.H., and Halbert, P., 2020, Annual marbled murrelet abundance and productivity surveys off central California (Zone 6), 1999-2019 (ver. 3.0, March 2020): U.S. Geological Survey data release, https://doi.org/10.5066/F75B01RW.

Felis, J.J., Kelsey, E.C., and Adams, J., 2019, Abundance and productivity of marbled murrelets (Brachyramphus marmoratus) off central California during the 2018 breeding season: U.S. Geological Survey Data Series 1107, 10 p., https://doi.org/10.3133/ds1107.

Henkel, L.A., 2004, At-sea distribution of marbled murrelets in San Luis Obispo County, California: Watsonville, California, H.T. Harvey and Associates, 14 p.
Henkel, L.A., and Peery, M.Z., 2008, Abundance and productivity of marbled murrelets off central California during the 2007 breeding season: Moss Landing, California, Moss Landing Marine Laboratories, 13 p., https://nrm.dfg.ca.gov/FileHandler.ashx?DocumentID= 17735\&inline.

Henry, R.W., 2017, Murrelet at sea abundance, productivity, and prey resources in Zone 6, chap. 7 of Halbert, P., and Singer, S.W., eds., Marbled murrelet landscape management plan for zone 6: Felton, California, California Department of Parks and Recreation, 235 p., http://www.parks.ca.gov/pages/29882/files/Z6Plan_FINAL_MASTER_V14_07-17.pdf.

Henry, R.W., and Tyler, W.B., 2017, Abundance and productivity of marbled murrelets off central California during the 2013-2016 breeding seasons: Santa Cruz, California, University of California Santa Cruz, 12 p., http:/www.parks.ca.gov/pages/29882/files/20132016MAMUAtSeaSurveyReport.pdf.

Henry, R.W., Tyler, W.B., and Peery, M.Z., 2012, Abundance and productivity of marbled murrelets off central California during the 2010 and 2011 breeding seasons: Half Moon Bay, California, California State Parks, 17 p.

Levy, P.S., and Lemeshow, S., 1991, Sampling of populations-Methods and applications ( $2 \mathrm{~d}$ ed.): New York, Wiley, $420 \mathrm{p}$.

Long, L.L., Ralph, C.J., and Miller, S.L., 2001, A new method for ageing marbled murrelets and the effect on productivity estimates: Pacific Seabirds, v. 28, no. 2, p. 82-91, https://www.fs.fed.us/psw/publications/long/psw_2001 long001.pdf.

Nelson, S.K., 1997, Marbled Murrelet (Brachyramphus marmoratus) (ver. 2.0), in Poole, A.F., and Gill, F.B., eds., The birds of North America: Ithaca, N.Y., Cornell Lab of Ornithology, https://doi.org/10.2173/bna.276.

Peery, M.Z., Becker, B.H., and Beissinger, S.R., 2006, Combining demographic and count-based approaches to identify source-sink dynamics of a threatened seabird: Ecological Applications, v. 16, no. 4, p. 1516-1528, https://doi.org/10.1890/10510761(2006)016[1516:CDACAT]2.0.CO;2.

Peery, M.Z., Becker, B.H., and Beissinger, S.R., 2007, Age ratios as estimators of productivity-Testing assumptions on a threatened seabird, the marbled murrelet (Brachyramphus Marmoratus): The Auk, v. 124, no. 1, p. 224-240, https://doi.org/10.1093/auk/124.1.224. 
Peery, M.Z., Beissinger, S.R., Newman, S.H., Burkett, E.B., and Williams, T.D., 2004, Applying the declining population paradigm-Diagnosing causes of poor reproduction in the marbled murrelet: Conservation Biology, v. 18, no. 4, p. 1088-1098, https://doi.org/10.1111/j.15231739.2004.00134.x.

Peery, M.Z., Hall, L.A., Harvey, J.T., and Henkel, L.A., 2008, Abundance and productivity of marbled murrelets off central California during the 2009 breeding season: Half Moon Bay, California, California State Parks, 10 p.

Peery, M.Z., and Henry, R.W., 2010, Abundance and productivity of marbled murrelets off central California during the 2009 breeding season: Half Moon Bay, California, California State Parks, 16 p.

Peery, M.Z., Newman, S.H., Storlazzi, C.D., and Beissinger, S.R., 2009, Meeting reproductive demands in a dynamic upwelling system-Foraging strategies of a pursuit-diving seabird, the marbled murrelet: The Condor, v. 111, no. 1, p. 120-134, https://doi.org/10.1525/cond.2009.080094.

Ralph, C.J., and Miller, S.L., 1995, Offshore population estimates of marbled murrelets in California, chap. 33 in Ralph, C.J., Hunt, G.L., Raphael, M.G., and Piatt, J.F., eds., Ecology and conservation of the marbled murrelet: U.S. Forest Service General Technical Report PSWGTR-152, p. 353-360, https://www.fs.usda.gov/treesearch/ pubs/27916.
R Core Team, 2016, R-A language and environment for statistical computing: Vienna, Austria, R Foundation for Statistical Computing, https://www.R-project.org/.

Strong, C.S., Keitt, B.S., Bradford, S., McIver, W.R., Palmer, C.J., and Gaffney, I., 1995, Distribution and population estimates of marbled murrelets at sea in Oregon during the summers of 1992 and 1993, chap. 32 in Ralph, C.J., Hunt, G.L., Jr., Raphael, M.G., and Piatt, J.F., eds., Ecology and conservation of the marbled murrelet: U.S. Forest Service General Technical Report PSWGTR-152, p. 339-352, https:/www.fs.usda.gov/treesearch/ pubs/27915.

Thomas, L., Buckland, S.T., Rexstad, E.A., Laake, J.L., Strindberg, S., Hedley, S.L., Bishop, J.R.B., Marques, T.A., and Burnham, K.P., 2010, Distance software-Design and analysis of distance sampling surveys for estimating population size: Journal of Applied Ecology, v. 47, no. 1, p. 5-14, https://doi.org/10.1111/j.1365-2664.2009.01737.x.

van Kempen, G.M.P., and van Vliet, L.J., 2000, Mean and variance of ratio estimators used in fluorescence ratio imaging: Cytometry, v. 39, no. 4, p. 300-305, https://doi.org/10.1002/(SICI)10970320(20000401)39:4<300::AID-CYTO8>3.0.CO;2-O. 

For more information concerning the research in this report, contact the Director, Western Ecological Research Center

U.S. Geological Survey

3020 State University Drive East

Sacramento, California 95819

https://www.usgs.gov/centers/werc

Publishing support provided by the Science Publishing Network, Sacramento Publishing Service Center 
c⿻

옹 을

응. 욱

을 혹

๘

离

믕

ब.

艝.

음. 을

$\overrightarrow{\overrightarrow{\overrightarrow{0}}}$

뜸

:

은

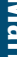

